\title{
Life-cycle Assessment Applied to Photovoltaic Energy: A Review
}

\author{
A.J. Aristizábal ${ }^{1}$, D.C. Sierra ${ }^{1}$ and J.A. Hernández ${ }^{2}$ \\ ${ }^{I}$ Departamento de Ingeniería, Universidad de Bogotá Jorge Tadeo Lozano, Bogotá, Colombia \\ ${ }^{2}$ Departamento de Energía Eléctrica y Automática, Universidad Nacional de Colombia, Medellín, Colombia
}

\begin{abstract}
The aim of this study is to evaluate the environmental performance of different photovoltaic solar energy systems through a review of the scientific literature concerning the life-cycle assessment applied to different photovoltaic systems and using the ISO 14040 and ISO 14044 standards. A comparison between solar photovoltaic systems and conventional systems, power generation is performed. Through the LCA the environmental impacts associated with the analyzed throughout their life cycle systems were tested. These results show, in terms of cumulative energy demand (CED), that for the case of monocrystalline silicon (mc-Si) as one of the most used raw materials, $75.8 \%$ of 5150 MJ corresponding to the manufacture of $1 \mathrm{~m} 2$ of photovoltaic module is required. As for the environmental performance, this technology produces only 0.7 $\mathrm{g} / \mathrm{GWh}$ of greenhouse gas emissions, compared to $3.7 \mathrm{~g} / \mathrm{GWh}$ and $44.3 \mathrm{~g} / \mathrm{GWh}$ produced from sources such as oil and coal, respectively. Photovoltaic technology generates lower emissions corresponds to Cadmium Tellurium (CdTe) solar cells with $0.3 \mathrm{~g} / \mathrm{KWh}$ of greenhouse gas emissions. First, it was found that, during manufacture of photovoltaic panels, a contribution of CO2equ emissions is mainly related to the transformation of silicon micro granular and it corresponds to $47.61 \%$ of emissions per GWP. Second, emissions are related to the assembly of the panels (18.39\%) and, thirdly, casting and production of wafers (16.54\% of GWP emissions).
\end{abstract} Keywords: Photovoltaic systems, environmental impact, life-cycle assessment, greenhouse gas emissions.

\section{Introduction}

At the international level it has been established consensus by institutions and guilds dedicated to research, related to environmental and energy, regarding the fact that the use of energy sources from fossil fuels generates a high environmental impact. Oil, coal, gas and its various applications in the transport, trade, industry and residential constitute one of the main causes of the negative effects caused to the environment, specifically with regard to the greenhouse effect that is produced by the emission of gases that cause global warming. However, initiatives of multilateral treaties such as the Kyoto Protocol, the Copenhagen Conference and recently the XXI International Conference on Climate Change, commit industrialized countries to reduce emissions of greenhouse gases. In addition under the Kyoto Protocol targets, signatory countries undertook to encourage energy supply through renewable energy sources and thus reduce the use of fossil resources; which helps mitigate environmental impacts of greenhouse gas emissions [1]. The proposed benefits for developing countries committed to reducing emissions, through mechanisms such as energy efficiency in areas of demand, production or processing and intelligent network systems, seek to mitigate the impacts of use of conventional energy. This will be possible with new renewable energy projects [2]. In the recent scenario, specifically, in the XXI International Conference on Climate Change it was established that the countries should work together to reduce carbon emissions as soon as possible and do everything necessary to keep global warming below $2{ }^{\circ} \mathrm{C}$ [3].

Currently, Colombia has national initiatives such as the enactment of document CONPES 3700 [4] and Law 1715 of 2014 [5], related to promoting the integration of renewable energy in the National Interconnected System (SIN). Today, the country supports energy demand from an array of hydraulic and thermal power generation using gas and coal (Figure 1). However, both thermoelectric and hydroelectric plants are located in areas far from the main center of consumption, which involves the construction of large transmission networks, creating inefficiencies in the system [6].

Diversification of the energy matrix through renewable sources, is a strategy that has been adopted by different countries like Spain, Portugal and Chile, parallel seeking an energy and environmental development [8]. Energy development is the increase in the provision and use of alternative energy services as a key aspect of economic development, since this determines how energy is produced and used and also it has a direct impact on social, economic and environmental dimensions of a country [9]. Obviously, one way to produce development and progress in the fight against climate change, is through the expansion of renewable energy, as long-term permit to extend the boundaries of human development without adversely affecting sustainability [10]. 


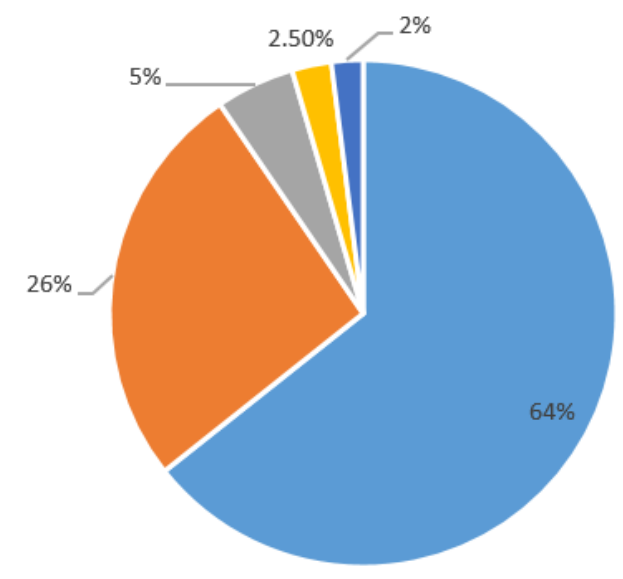

" Hydro $\|$ Gas $\|$ Coal $\|$ Renewables $\|$ Cogeneration

Figure 1. Current energy matrix in Colombia according to Colombian national strategic plan: 2050 [7].

Photovoltaics on a large scale can extend the portfolio of the energy matrix for the supply chain. The use of this energy source has increased worldwide due to the active cooperation of countries and their governmental policies [11]. The increased use of photovoltaic systems, is due to its minimal impact on the environment during its operation; because it uses primary energy from the sun directly and does not require processing of high energy density materials such as coal, water drops or oil. In addition, solar energy has a level of greenhouse gas emissions virtually null [12].

\section{Methodology}

For the review of the scientific literature concerning the subject, the following criteria were applied: 1) they correspond to studies published in scientific journals internationally recognized work and 2) that the application of life-cycle assessment will focus on the analysis of photovoltaic systems, including different types of solar panels that are in the market (monocrystalline, polycrystalline and CdTe panels).

Each source of information its main guidelines as to the structure were extracted, methodology, the parameters taken into account for the assessment and a brief summary of the results obtained during the application of the analysis. Likewise, taken into account in the revised work they were covered under the ISO 14040 (2006) and ISO 14044 (2006) and guidelines of Data System Life Cycle International Reference (ILCDHandbook, 2010). In each information source revised, the methodology is analyzed and the relevant conclusions as to input and output parameters used [13] [14].

Through life-cycle assessment the potential impacts of the photovoltaic system are evaluated throughout its lifetime. This approach includes aspects related to obtaining and processing raw materials, the manufacture of photovoltaic solar panels, transport and final disposal, analyzing the critical points for environmental addressing [15].

To apply the life-cycle assessment is necessary to consider four phases (Figure 2): target definition and scope, inventory analysis, impact assessment and interpretation of results related to environmental impacts [16].

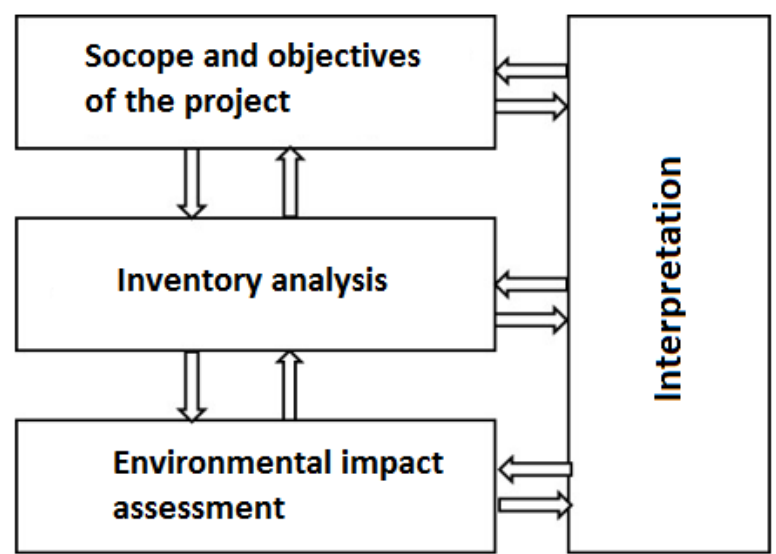

Figure 2. Framework of life-cycle assessment (ISO 14040, 2006). 
Moreover, the life-cycle assessment is recognized as an effective tool to assess the sustainability of the various renewable energy sources and to help policy makers to choose the best source of energy for a specific purpose [17].

\section{Results And Discussion}

The analysis in each of the reviews of literature leads us to determine that the behavior stage of the life cycle of PV it focuses according to Fthenakis et al., (2010).

Figure 3 shows the flowchart of the life cycle for a solar photovoltaic system. The stages of the life cycle of the generation of this type of energy are: (i) the extraction of raw materials, (ii) processing and purification, (iii) module manufacturing (balance of system) and its components, (iv) the installation and use of systems and (v) Dismantling and disposal or recycling [18].

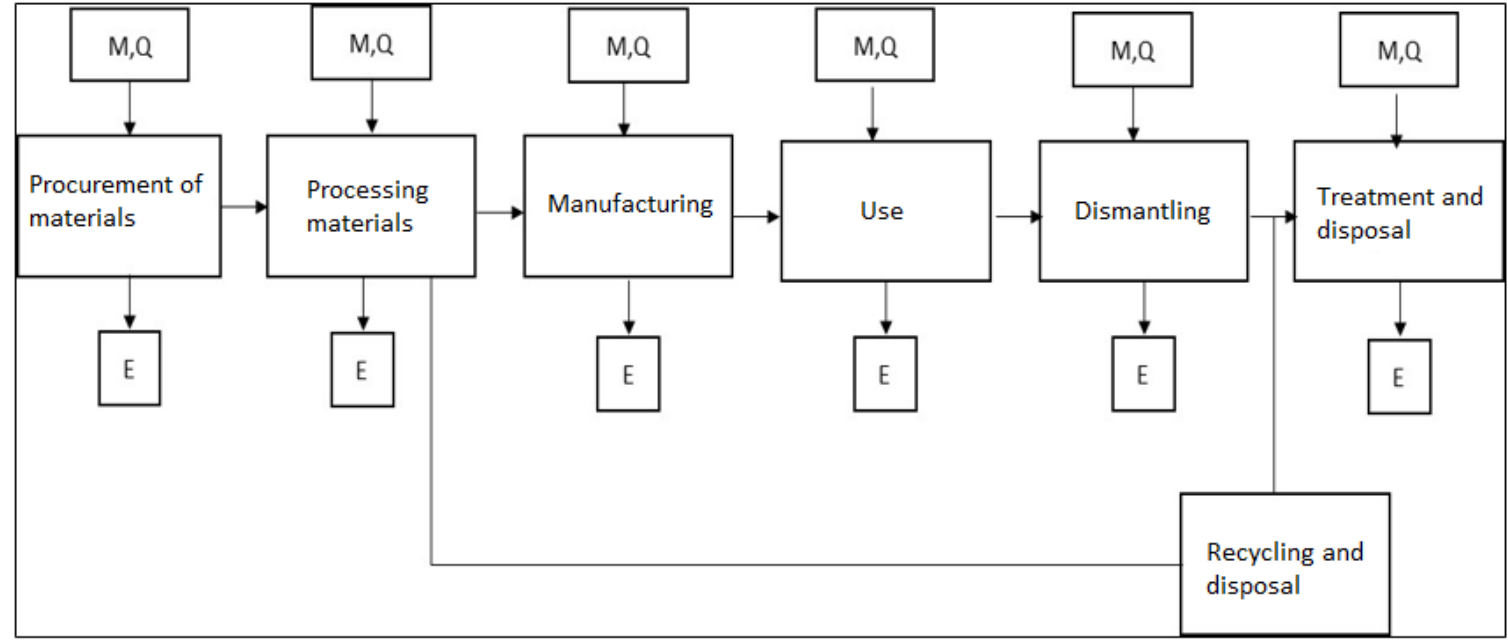

Figure 3. Flowchart life cycle for a photovoltaic system [19].

In each phase are taken as inputs materials (M) and a quantity of heat or specific energy (Q), spent on the operation or thread, and delivering as a final result a surplus of emissions (E), that they are thrown into the environment. For this it is important to define a functional unit, which it is the quantified performance of a product system for use as a reference unit [20]. The functional unit (fu) is defined as $1 \mathrm{kWh}$ of electricity generated from one photovoltaic generation system, and likewise the conversion efficiency of the photovoltaic panel is assumed to $20 \%$, as recommended by the International Energy Agency (IEA) [21]

As a first analysis, R. Battisti and A. Corrado, (2005) made an inventory of materials and energy resources used at each stage of production of a photovoltaic system, which correspond to the input variables of the system. As output variables, emissions production stages are analyzed, as shown in Figure 4.

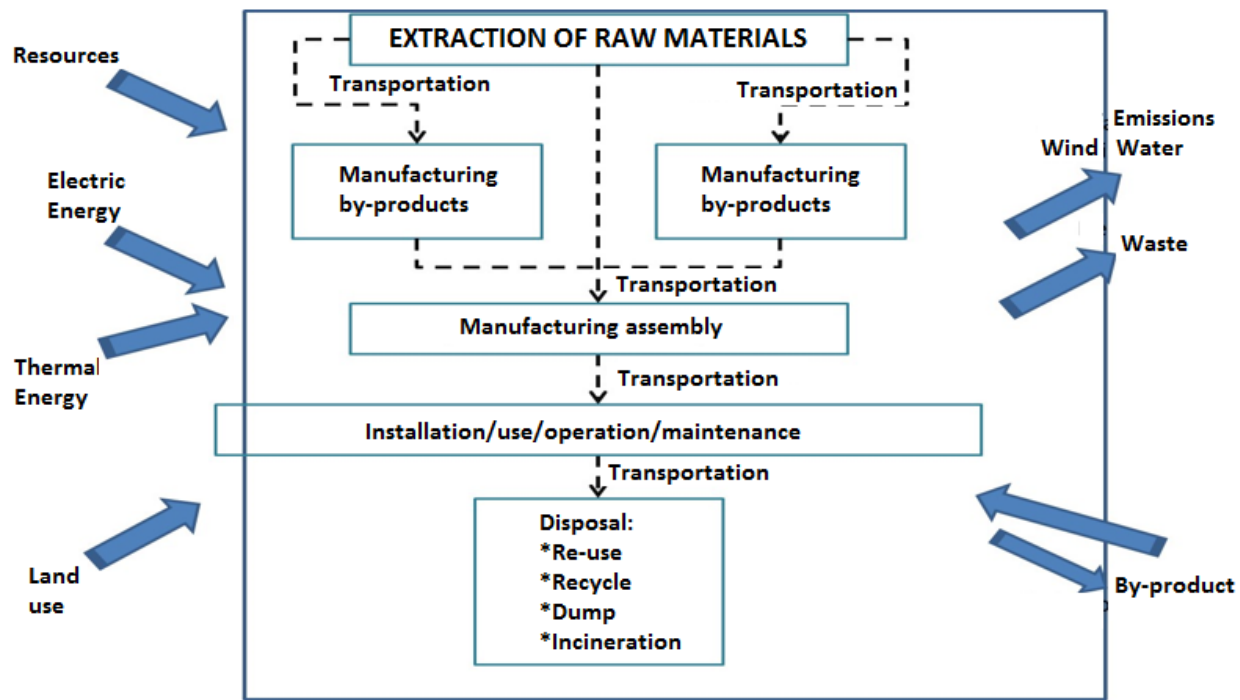

Figure 4. Inputs and outputs of the system for life cycle inventory. Adapted from [22]. 
For some authors, the life-cycle assessment must be done from an approach that considers the raw materials used and manufacture of photovoltaic panels. In this case the life cycle begins with the mining of raw materials (that is to say; quartz sand for silicon photovoltaic panels and $\mathrm{Zn}$ and $\mathrm{Cu}$ for $\mathrm{CdTe}$ panels) and continues its processing and purification as shown in Figure 5a [19]. The first process is the removal of silica sand: this phase is done by reducing the sand in an arc furnace, to metallurgical grade silicon, which it must be purified to an "electronic grade" or silicon "solar grade"; usually through a process called "Siemens". The lifecycle assessment crystalline of silicon, begins with an inventory collectively established by US and European photovoltaic companies, that are participating in the Clean Glass Project [22].

The second process includes inventories lifecycle of minor metals used in thin film photovoltaic systems as Cd, In, Mo, and Se. The cycle begins with the production of cadmium (Cd) and tellurium (Te) which are by-products of melting $\mathrm{Cu}$ and $\mathrm{Zn}$ minerals, respectively (Figure $5 \mathrm{~b}$ ). Te is obtained from waste streams $\mathrm{Zn}$, such as particles collected on air pollutants through control equipment and sludges collected electrolyte in the purification steps.

After cementation with copper, the CdTe is leached with caustic soda to produce a solution of sodium tellurium used to obtain Te y TeO2. This gives to $\mathrm{Cd}$ and Te semiconductive characteristics [18] [19].

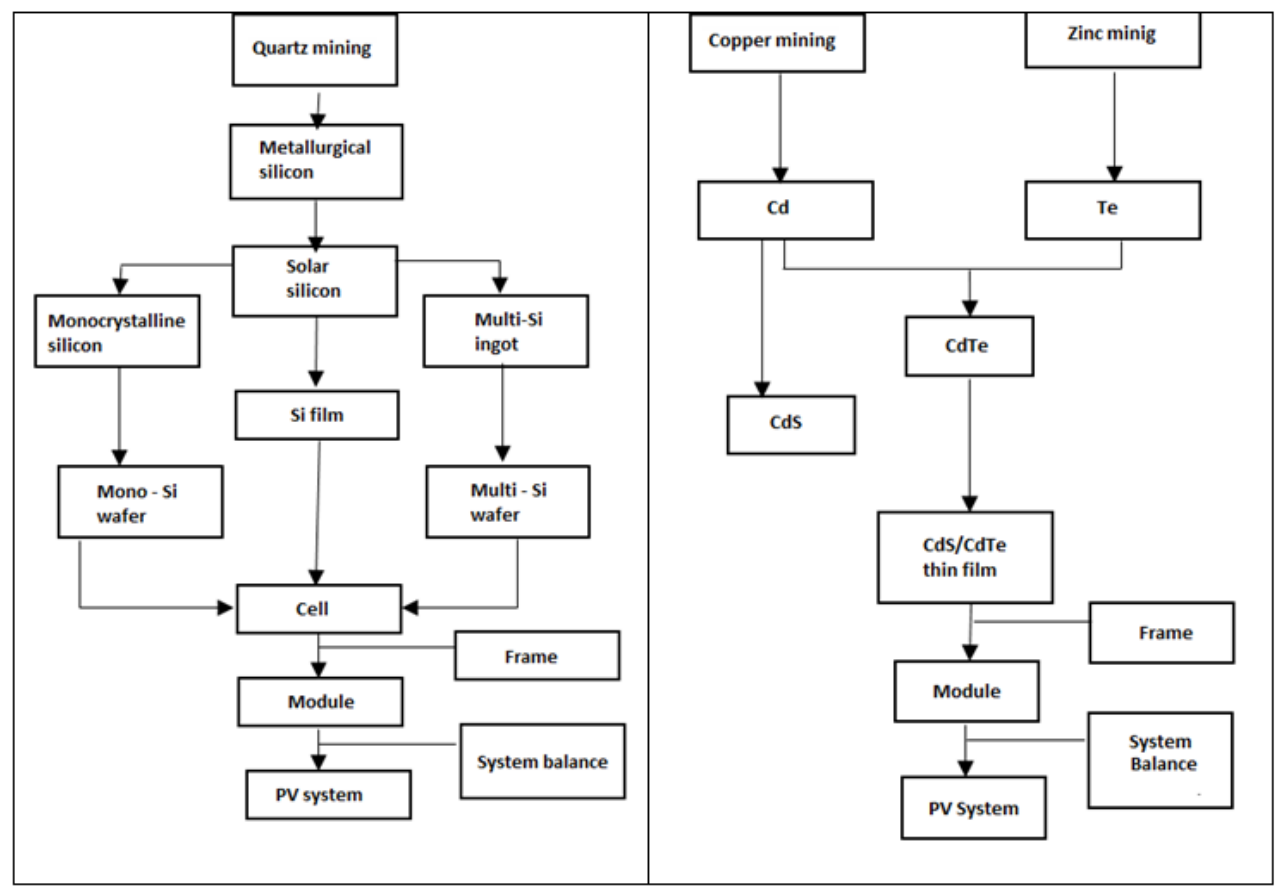

Fig. 5a. Photovoltaic panels Silicon System.

Fig. 5b. Photovoltaic panels system of CdTe.

In some research the application of life-cycle assessment builds on the CED indicator (Cumulative Energy Demand) as it is proposed by Battisti y Corrado (2005). The results show the different contributions, in terms of CED of the materials and processes involved in production of modules with monocrystalline silicon technology (mc-Si) (figure 6). CED for obtaining electronic grade silicon corresponds to $75.8 \%$ of the total energy used and it corresponds to $5.150 \mathrm{MJ}$ for producing $1 \mathrm{~m} 2$ of photovoltaic module.

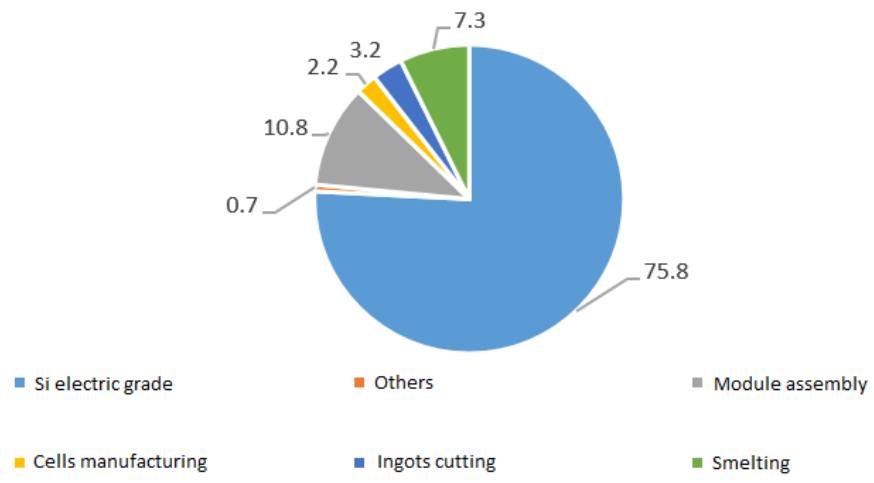

Figure 6. Energy input for the production of $1 \mathrm{~m} 2$ of photovoltaic module. CED indicator $(100 \%=5150 \mathrm{MJ})$ [22]. 
On the other hand,Crawford et al. (2006), proposes a life-cycle assessment for a photovoltaic system, including the possibility of cogeneration, through heat recovery devices [23]. This process improves the balance of energy recovered.

This work shows that the lower the energy used in the life cycle of a product, the lower the emissions to be taken into threads. Energy requirements demanded to photovoltaic systems from utility, are directly related to the emission levels they generate [24].

Crawford's et al. (2006) analysis, showed that approximately $76 \%$ of the energy consumed during the lifecycle, corresponds to the power generation and major emissions correspond to the removal or disposal of cadmium and other heavy metals as chromium, lead, mercury and nickel [23]. However, the levels of global emissions of photovoltaic systems are lower, compared with those generated with other energy sources $(44.3 \%$ emission of energy from oil (Figure 7)).

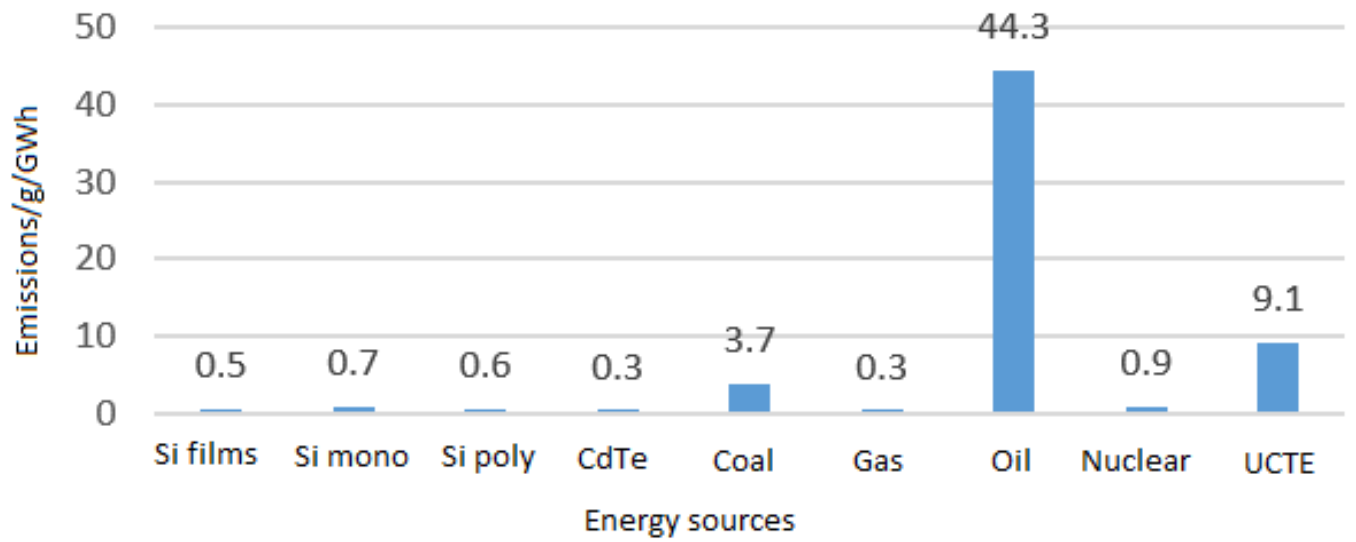

Figure 7. Atmospheric Cd emissions for photovoltaic systems in southern Europe of $1.700 \mathrm{kWh} / \mathrm{m} 2$-year [18].

Stoppato (2008), performs the evaluation of environmental performance of a photovoltaic generation system supported by life-cycle assessment. The analysis begins with the mass and energy balances from extraction of silicon to the assembly phase of the photovoltaic panel. The author presents an analytical scheme shown in Figure 8 in which the phases are evident to consider. During the development of the methodology a progressive balance of the unit processes is established, with reference: energy consumption and the use of raw material for the production of photovoltaic module [25].

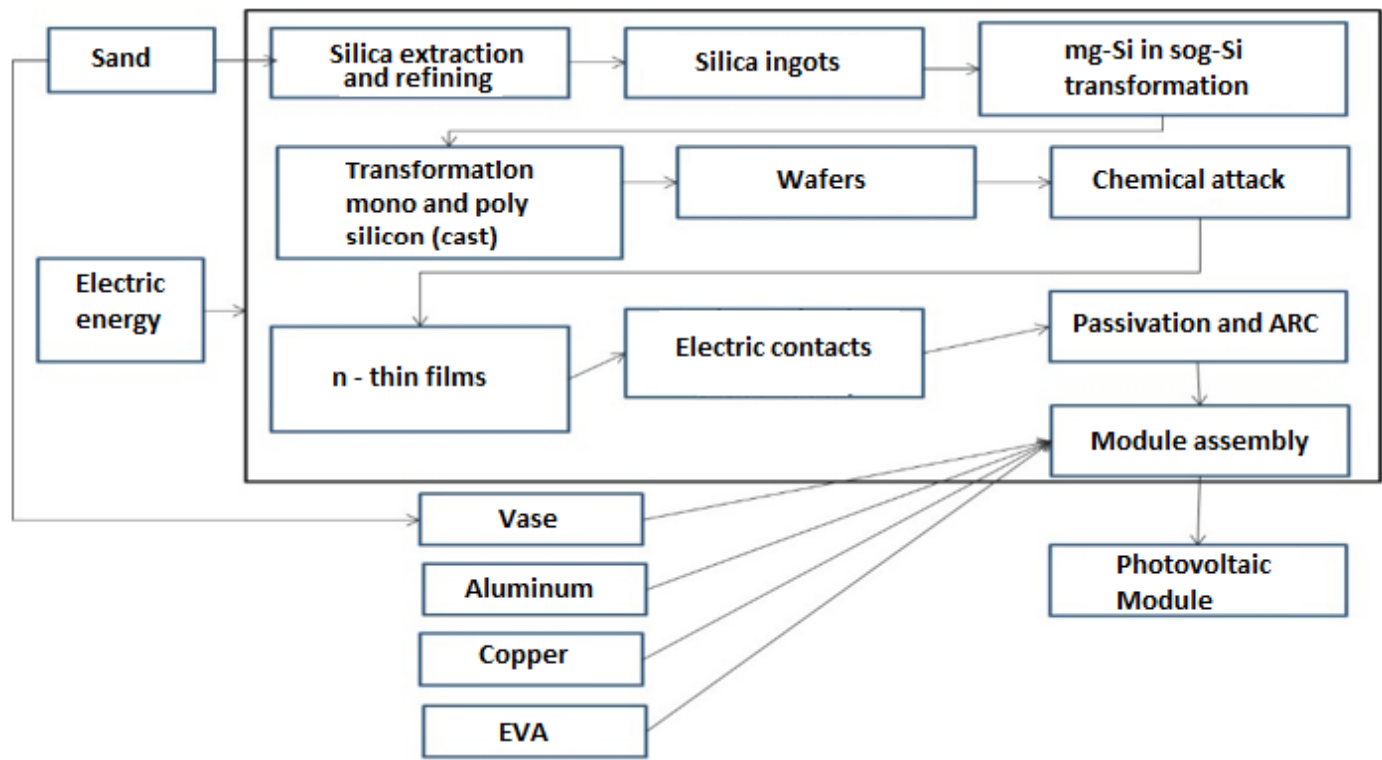

Figure 8. Scheme of the production process of a photovoltaic module [25].

Among the most relevant results, is the determination of $\mathrm{CO} 2 \mathrm{eq}$ emissions during different stages of the manufacturing process of the panels and installation of the photovoltaic system (Figure 9). 


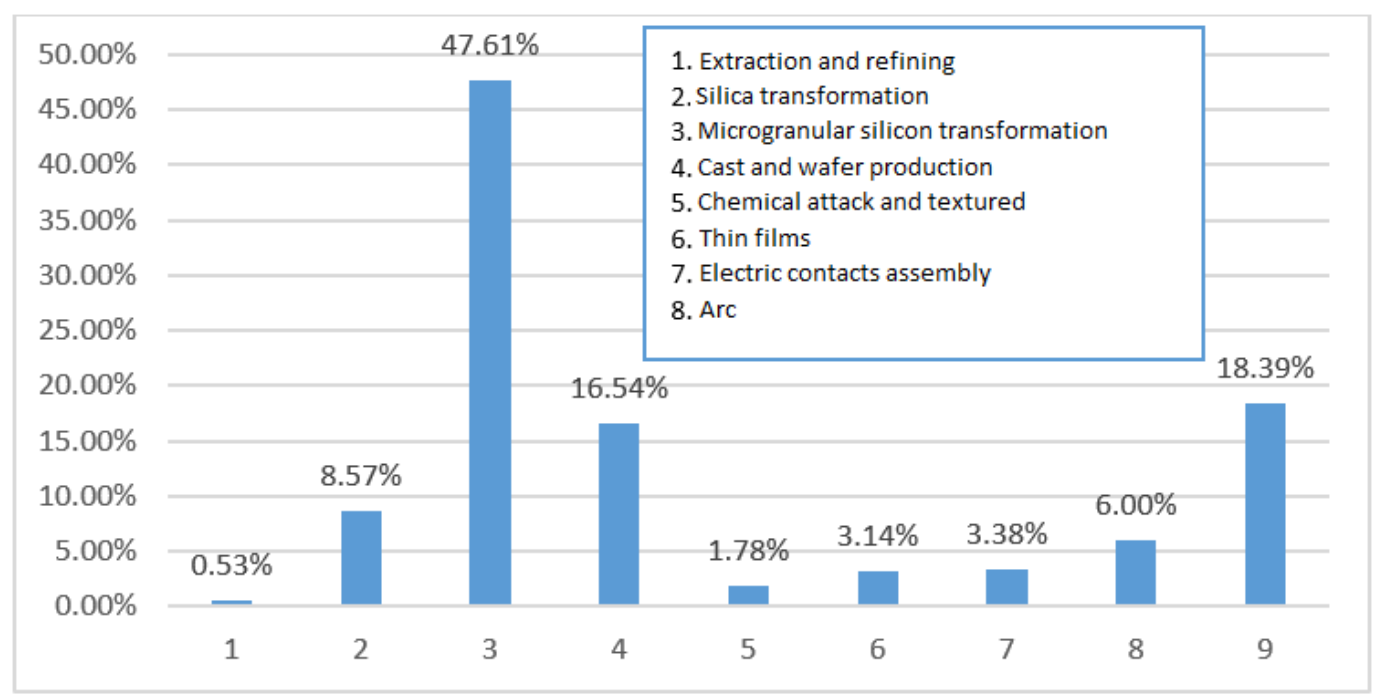

Figure 9. $\mathrm{CO} 2 \mathrm{eq}$ emissions in various stages of manufacture of the panels and installation of photovoltaic system [25].

The analysis shows that the most critical phases, are the transformation of metallic silicon in solar silicon $(1,190.1 \mathrm{MJ} / \mathrm{panel})$ and installation of photovoltaic panel, phase involving the spending of 272.7 $\mathrm{MJ} /$ panel. This final process is characterized by a high energy demand. The study demonstrates the importance of using the energy through the use of aluminum frames and the use of natural lighting in buildings, for example, through the location of glass tiles on the roof [26].

García-Valverde (2009) conducted a life-cycle assessment for evaluating the energetic use and potential environmental impacts of a photovoltaic autonomous system of $4.2 \mathrm{~kW}$ at the University of Murcia in Spain. It was found that the recovery time for the energy expended in the manufacturing process of the panel is equivalent to 9 years; while emissions of $\mathrm{CO} 2 \mathrm{eq}$ are estimated at $131 \mathrm{gCO} 2 \mathrm{eq} / \mathrm{kWh}$ [27].

The life-cycle assessment evaluates if future systems will impact on the environment and thus, determine the regimes of work and efficiency which can have both autonomous photovoltaic systems, as interconnected with the grid [28].

Semper et al., (2011) assesses the life cycle of a poly crystalline photovoltaic system of $200 \mathrm{~kW}$. it is concluded that more than $84 \%$ of the energy consumed by the PV system during its life cycle; corresponds to energy consumed during the production process of photovoltaic modules [29].

According to Figure 10, the authors analyze the components and specific activities of implementation of photovoltaic modules, as cabling, electrical interconnection devices, photovoltaic modules, support structures, site preparation, enclosures and collection points for waste. In addition to establishing the potential impacts of photovoltaic panels, the life-cycle assessment also allows comparative processes between traditional systems and photovoltaic power systems.

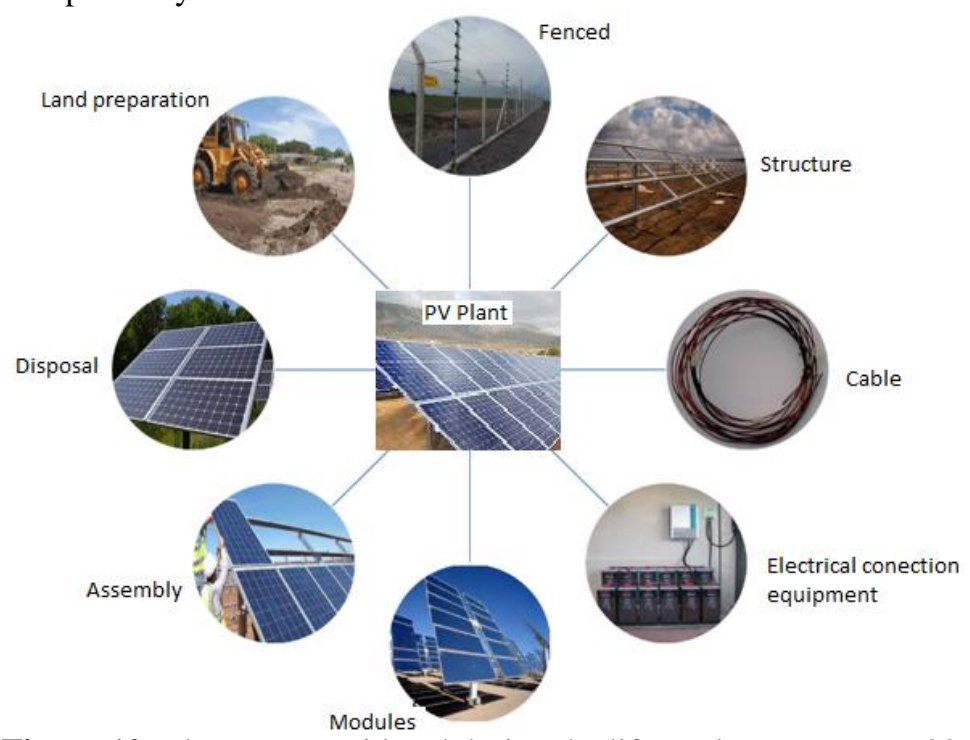

Figure 10. Elements considered during the life-cycle assessment [30]. 
The results of the environmental impact associated with the production of $1 \mathrm{kWh}$ of electricity by the photovoltaic plant of Marsciano is compared with some processes that were taken from the base Ecoinvent: Mix electricity generation, natural gas, coal generation, and oil power plant. The first is represented by the Italian energy mix (imported energy 14,85\%; coal 7,73\%; hydroelectric 17,74\%; gas 32,77\%; Oil 26,1\%; PV energy $0,00204 \%$; wind $0,183 \%$ ).

Three environmental aspects are highlighted: health, ecosystem quality and resources. In Figure 11, it is shown the comparison between the photovoltaic plant of Marsciano (Italy) and some traditional energy systems for $1 \mathrm{kWh}$ of energy production.

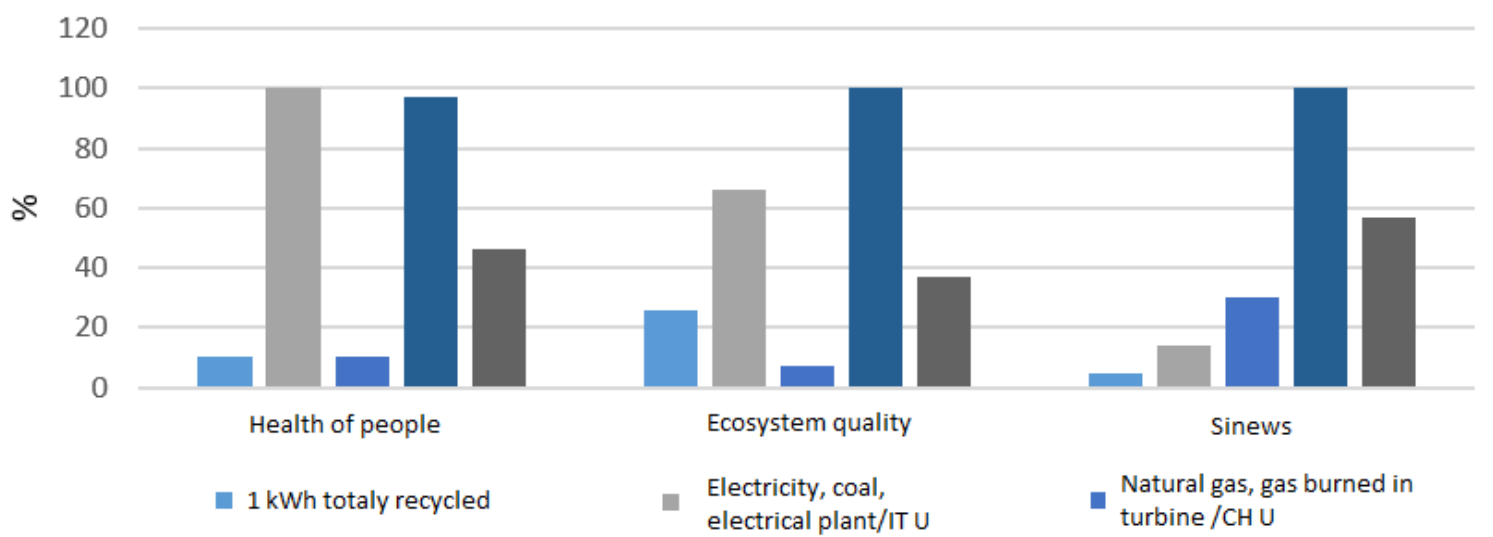

Figure 11. Comparison between the photovoltaic plant of Marsciano (Italy) and some traditional energy systems for $1 \mathrm{kWh}$ of energy production [30].

The involvement of health is better for photovoltaic technology and natural gas with a negative contribution of $10 \%$, instead of traditional energy production systems with about $40-100 \%$ involvement. Globally, the total power generation by the end of 2013, $78.3 \%$ came on fossil fuels. However, policies and contributions of technologies allowed alternative energies involved with 19,1\% of production. [35].

The cost per $\mathrm{kW}$ of conventional energy in Colombia, is closely linked to the hydraulic generation; is associated with the level of reservoirs and fluctuates between \$0.017 USD and \$0.073USD per kWh depending on the greater or lesser amount of water it is counted in reservoirs, respectively [7].

\section{Conclusion}

With the methodology of Life Cycle Analysis is shown that the negative impact of electricity produced from oil is much higher than electricity from photovoltaic systems. Similar results are obtained in the way resources are consumed for obtaining electrical energy.

The results are accurate in that the thin layer of amorphous silicon panels produces higher net environmental benefit, in relation to technologies of monocrystalline crystals. This is related to the consumption of less energy for recycling of thin layer of amorphous silicon panels. The life-cycle assessment of a $100 \mathrm{~kW}$ photovoltaic system made of cadmium telluride (CdTe), based on the global warming potential (GWP), fossil fuel consumption (FFC), the payback time of energy (EPBT) and recovery time of CO2 (CO2PBT); demonstrate that this panel is more environmentally compatible than their similar type monocrystalline silicon.

When comparing photovoltaic systems and conventional systems for power generation with big scale, as hydro, we can say that, although prices of photovoltaic technology have been growing in the last decade, they are still at a level of energy parity. But nevertheless, development programs being promoted in the country and worldwide allow to be optimistic about the process of diversification of the energy matrix of Colombia.

\section{References}

[1] J. H. Braslavsky, J. R. Wall, and L. J. Reedman, "Optimal distributed energy resources and the cost of reduced greenhouse gas emissions in a large retail shopping centre," Appl. Energy, vol. 155, pp. 120-130, 2015.

[2] R. Alberto and M. Rioseco, "Inserción de generadores de energía renovable en redes de distribución,” 2007.

[3] (Organización De Las Naciones Unidas) Onu, "Convención Marco sobre el Cambio Climático,” vol. 21930, p. 40, 2015.

[4] Departamento Nacional de planeacion. (2011) Plan Nacional De Adaptacion Al Cambio Climatico

[5] C. de C. Congreso de Colombia, "Ley N 1715 Del 13 De Mayo De 2014," no. May, p. 26, 2014

[6] F. Peter, R. Rüther, and N. C. Filho, "The in fl uence of distributed generation penetration levels on energy markets," Energy Policy, vol. 62, pp. 226-235, 2013.

[7] Unidad de Planeamiento Minero Energético and Banco Interamericano de Desarrollo, Integración de las energías renovables no convencionales en Colombia. 2015.

[8] B. Moreno, A. J. López, and M. T. García-álvarez, "The electricity prices in the European Union . The role of renewable energies and regulatory electric market reforms," Energy, vol. 48, no. 1, pp. 307-313, 2012 
[9] T. B. Johansson and W. Turkenburg, "Policies for renewable energy in the European Union and its member states: an overview," Energy Sustain. Dev., vol. 8, no. 1, pp. 5-24, 2004.

[10] F. P. E. M. A. Mundial, “La Inversión En Proyectos De Energía Renovable, La Experiencia Del Fmam,” p. $36,2009$.

[11] B. Shen, G. Ghatikar, Z. Lei, J. Li, G. Wikler, and P. Martin, "The role of regulatory reforms, market changes, and technology development to make demand response a viable resource in meeting energy challenges," Appl. Energy, vol. 130, pp. 814-823, 2014.

[12] E. Alzamora, "Evaluación Técnica y Financiera de Alternativas Energéticas Renovables no Convencionales para incorporar a la Gestión Energética del Casino de Suboficiales Badilla , III Brigada de la Fuerza Aérea de Chile , Puerto Montt .,” 2012.

[13] International Reference Life cycle Data System ILCD-Handbook, 2010

[14] International Organization for Standardization, "Ntc-Iso 14044.," Gestión Ambient. análisis del ciclo vida., no. 571, p. $16,2007$.

[15] a. Esmaeeli, S. M., and Kazemi, "Stochastic Unit Commitment of Wind Farms Based on Mixed-Integer Linear Formulation," IEEE PES Innov. Smart Grid Technol., pp. 1-6, 2012.

[16] International Organization for Standardization, "Ntc-Iso 14040:2006, Environmental management life cycle assessment- principles and framework

[17] Singh Anoop, Olsen Stig Irving, Pant Deepak. Importance of life cycle assessment of renewable energy sources. Life cycle assessment of renewable energy sources. Green energy and technology. London: Springer; 978-1-4471- 5363-42013; 1

[18] V. M. Fthenakis and H. C. Kim, "CdTe photovoltaics: Life cycle environmental profile and comparisons," Thin Solid Films, vol. 515, no. 15 SPEC. ISS., pp. 5961-5963, 2007.

[19] H. Kim, K. Cha, V. M. Fthenakis, P. Sinha, and T. Hur, "Life cycle assessment of cadmium telluride photovoltaic (CdTe PV) systems," Sol. Energy, vol. 103, pp. 78-88, 2014.

[20] Ji-Yong Lee, Kyoung-Hoon Cha, Tae-Won Lim, Tak Hur, "Eco-efficiency of H2 and fuel cell buses," Int. J. Hydrogen Energy 36, 17541765.

[21] Fthenakis. V, Kim. H.C, Alsema. E, "Methodology Guidelines on Life Cycle Assessment of Photovoltaic Electricity. Second ed. International Energy Agency, Report IEA - PVPS

[22] R. Battisti and A. Corrado, "Evaluation of technical improvements of photovoltaic systems through life cycle assessment methodology," Energy, vol. 30, no. 7, pp. 952-967, 2005.

[23] R. H. Crawford, G. J. Treloar, R. J. Fuller, and M. Bazilian, "Life-cycle energy analysis of building integrated photovoltaic systems (BiPVs) with heat recovery unit," Renew. Sustain. Energy Rev., vol. 10, no. 6, pp. 559-575, 2006.

[24] V. Raman and G. N. Tiwari, "Life cycle cost analysis of HPVT air collector under different Indian climatic conditions," Energy Policy, vol. 36, no. 2, pp. 603-611, 2008.

[25] A. Stoppato, "Life cycle assessment of photovoltaic electricity generation," 19th Int. Conf. Effic. Cost, Optim. Simul. Environ. Impactof Energy Syst. ECOS 2006, vol. 33, no. 2, pp. 224-232, 2008.

[26] B. Azzopardi and J. Mutale, "Life cycle analysis for future photovoltaic systems using hybrid solar cells," Renew. Sustain. Energy Rev., vol. 14, no. 3, pp. 1130-1134, 2010.

[28] P. Balcombe, D. Rigby, and A. Azapagic, "Environmental impacts of microgeneration: Integrating solar PV, Stirling engine CHP and battery storage," Appl. Energy, vol. 139, pp. 245-259, 2015.

[29] A. Sumper, M. Robledo-García, R. Villafáfila-Robles, J. Bergas-Jané, and J. Andrés-Peiró, "Life-cycle assessment of a photovoltaic system in Catalonia (Spain),” Renew. Sustain. Energy Rev., vol. 15, no. 8, pp. 3888-3896, 2011

[30] U. Desideri, S. Proietti, F. Zepparelli, P. Sdringola, and S. Bini, "Life Cycle Assessment of a ground-mounted 1778kWp photovoltaic plant and comparison with traditional energy production systems," Appl. Energy, vol. 97, pp. 930-943, 2012.

[31] H. García, A. Correodor, L. Calderón, and M. Gómez, "Análisis costo beneficio de energías renovables no convencionales en Colombia," Doc. Prep. para WWF, p. 90, 2013.

[32] N. Kittner, S. H. Gheewala, and R. M. Kamens, "An environmental life cycle comparison of single-crystalline and amorphoussilicon thin-film photovoltaic systems in Thailand," Energy Sustain. Dev., vol. 17, no. 6, pp. 605-614, 2013.

[33] C. Mondial, D. E. L. É. Gie, Y. D. Kim, L. Birnbaum, G. Ward, and C. Frei, "Recursos energéticos globales," World Energy Counc., p. 27, 2013.

[34] US Department of Energy - Energy Efficiency and Renewable Energy, “What is the energy payback for PV,” Int. J., pp. 1-2, 2004.

[35] REN21, Renewables 2015. Global Status Report (Paris, 2015). 